\title{
Security Mapping of a Usage Based Cloud System
}

\author{
Kamatchi R. \\ Amity University, Mumbai \\ rkamatchiiyer@gmail.com \\ Kimaya Ambekar \\ K. J. Somaiya Institute of Management Studies \& Research, Mumbai. \\ kimaya.ambekar@somaiya.edu \\ Yash Parikh \\ IndusInd Bank, Mumbai \\ yash0924@gmail.com
}

Received: October 31, 2016 Accepted: December 30, 2016 Published: December 31, 2016

DOI: 10.5296/npa.v8i4.10240

URL: http://dx.doi.org/10.5296/npa.v8i4.10240

\begin{abstract}
The popularity of cloud computing technology is increasing tremendously. There is no disagreement about the effectiveness of the data storage and the data transition techniques of clouds. Earlier it used distributed computing just for sharing resources. However, with technology advancement, cloud computing has become more and more powerful as well as more adaptive in various business sectors. However, with the increase in number of users, there is also an increase in the security threats affecting the users' privacy, personal data, identity and confidentiality. In this paper, we have aimed at categorizing security and privacy threats based on the kind of usage of cloud. We have also presented an algorithm to find the appropriate solution to address the security and privacy related issues as per the usage category. The case study method is adopted to analyze the pertinence of the algorithm through relevant real time cases. This paper helps in improving security and privacy of cloud technology users without compromising the benefits of data storage.
\end{abstract}

Keywords: Cloud computing, Security levels, security attacks, solutions

\section{Introduction}

Cloud computing is a new dimension to the information Technology with extensive benefits. It is a combination of older technologies in new wrapper. It incorporates utility computing, virtualization, web 2.0, Service Oriented Architecture (SOA) and some concepts 
of distributed computing like grid and cluster computing. Earlier it used distributed computing just for sharing resources. However, with technology advancement, cloud computing has become more and more powerful as well as more adaptive in various business sectors.

Cloud computing can be seen as an elastic, on-demand scalable, pay-as-you-go model. Due to its versatile characteristics, not only big market players but also SMEs also adapting cloud computing.

Depending upon its methods of deployment, cloud computing is divided into four types:

- Public Cloud: It is a type of cloud, which is hosted and maintained by cloud service provider (CSP). All users share the infrastructure.

- Private Cloud: The services are dedicated for an organization. It can be maintained on site or off site.

- Hybrid Cloud: This will be a combination of more than two deployment options. An organization can opt for one service from public and other from private cloud provider

- Community Cloud: Organizations who share same goal, mission etc can connect and use cloud services provided by CSP.

Depending upon the types of services it provides, cloud computing majorly divided into following three types:

- Infrastructure-as-a-service:

IaaS service providers like, Amazon (EC2), Rackspace provide complete Infrastructure, storage, networks, computational power etc. Majorly, IT administrators, IT managers use this type of service.

- Platform as a service:

PaaS providers like Microsoft Azure, EngineYard, and Force.com provide application hosting platforms (E.g. Linux, android), platforms on which applications can be created and database. Users does not own infrastructure but have control over the applications they create. These services are mostly used by developers and researchers.

\section{- Software as a service:}

SaaS providers like GoogleApps, Salesforce provide applications or software as a service which users can run using browsers. Users do not worry about installation, up-gradation. These services are mainly used by non-technical users and middle level as well as high-level management people.

There are variety of services present in the cloud basket and as a major advantage of cloud, it reduces Capex (capital expenditure) and gives scope to the organization to invest more in OpeX (Operational Expenditure).With all the advantages, the major disadvantage can be seen in security area. Security area shows the major lacuna which needs to be filled using various ways. Not one way can fulfill all the security requirements. A cloud service providers need to use various security measures to create a complete secure experience for the cloud users. The security requirements depend upon various factors. The factors can be seen as types of users, types of services users use, or types of deployment methods CSP uses etc. While creating a complete security policy for a particular individual or an organization, cloud service provider needs to consider all such things. [1]

This paper is organized in seven sections. Current section describes about cloud 
computing as latest technology. The next section (section 2) talks about types of users in cloud depending upon the need and usage. Section 3 identifies different levels of security for organizations and cloud service providers. This section also maps security levels with types of users. In Section 4, we try to identify different threats and attack on cloud services on the basis of security levels we identified earlier. Section 5 presented an algorithm which will help any type of user to find out the security level he/she may need, threats and/or attacks they may face and possible measures they can take. Section 6 elaborates the algorithm from section 5 using a hypothetical case. In section 7 we conclude and propose some future work.

\section{Cloud Users}

It is very important to understand the users and usage models. When cloud service providers will have the clear picture of it then only they can create a concrete security plan for organizations. According to the research, there are following types of users who uses cloud services for different reasons [2].

\subsection{Naive users:}

These users use browsers or applications to access cloud services. Instead of using local applications/ softwares, these users can use them from browsers like Mozilla or Chrome. These types of cloud services reduce the critical installations and update tasks of users. Users should not be worried about the handling and storage of the application. Cloud service providers manage these things. These types of services remove or decrease the dependency on particular operating system. These services will be in the form of web services or application

\subsection{Virtualized device users:}

These users are more specialized than the naïve users. They use virtualized environment to access different services. Powerful Servers may use different softwares like KVM, VMware vSphere or virtual bridge verde etc to create virtualized environment for users. There servers may have different applications for users. Users just need access through internet to those virtualized machines. E.g., User can have LINUX operating system on his/her system and can access a virtualized desktop on cloud with windows operating system.

\subsection{Software developers/Business developers/researchers:}

Software/business developers or researchers may need resources like computational power, storage or different platforms and IDE (Integrated Development Environment) etc. There might be fluctuation in the number of resources needed at a given time. E.g.At the time of compilation, linking or testing an individual may need more resources. On the other hand, there may be a situation where a project may need more people to finish it on time. In such scenarios, organizations may need more certified platforms to work on. Applications like Team foundation server or github can help the organizations to manage coding and deployment of the applications prepared by different developers across. In short, Organization's needs may be flexible and elastic and those can be fulfilled by cloud services. 


\subsection{IT System Administrators:}

Every organization needs extensive IT support. Bigger organizations have their own datacenter. Smaller organizations cannot afford the data centers. Still they also have their servers and data storage devices. Since computational power and data storage-backup are essentials, every organization has System Administrator to handle the datacenters. These users do not use these services directly but deploy for the organizational employees. Administrators should know the resource requirements and security policies of the organization. These users deploy applications and platforms on the underlined hardware. These users are responsible for the availability, reliability, and scalability of the resources needed by the organization.

\section{Security Levels}

Cloud computing security has different levels. [3] These levels help organizations and CSPs (Cloud service providers) to implement security measures. These can be divided in following broad categories:

\subsection{Physical Level}

Any organizations having own data center or CSP having own cloud services, need to have this primitive level security. In this level, securing the campus around the data centers, employing security guards, access regulations, noting down the essential information of the visitors etc can be employed throughout the area. This level is vulnerable for infrastructure damage due to physical/natural disaster, human accidents, and malicious attacks from internal or external personnel.

\subsection{Host/Virtual Level}

Virtualization is a heart of Cloud computing. CSPs use virtualized environment to provide services to different users. CSPs cannot share the information about virtual images, virtual operating systems they used.

Intruders try to intrude from hypervisor so its security becomes very essential. [4] Hypervisors are always single point of security failure. If one hypervisor is hijacked by attacker then it can damage the whole cloud system. [5]

\subsection{Network Level}

Networks become essential connectors of cloud computing. Users are connected to the cloud service through networks. The data communication happens via network. That is why it is very necessary to secure the network first. There are varieties of attacks that can be simulated through it. It can ranges from passive to active attacks and can hamper confidentiality, integrity and availability. Cloud service providers should ensure the protocols used are secured and robust. [6] [7]

\subsection{Interface Level}

Interface for the services offered to the users and the operating system on which the services run should be secured. CSPs these days create services on linux operating system, which is open source and gives more security than other Os [4]. E.g. IBM bluemix is cloud 
service based on Linux; on the other hand, Microsoft azure is built on windows operating system. [8]

\subsection{Operating System Level}

Operating system is very important part of the cloud host machine. Apart from bare metal hypervisor, all hypervisors have an operating system. Each virtual machine sits on the operating system that is why operating system security is very important. If operating system is compromised then all virtual machines can be in attack zone. [9] [10] [11]

\subsection{Database level}

Data becomes very important asset for any organization. Users, which are moving to the cloud services, may need to store the data to the CSP side. It is very essential to understand the importance of the data at rest on CSP's servers. Most CSPs encrypt data while on transit but only 8.4\% CSPs do not encrypt data white at rest. The organizations that offer sensitive data e.g. financial organizations need extra level of security on database. [7] [12] [13] [14]

\subsection{Application Level:}

The application level of security is the last level of security. This will decide who is authorized to access the services and how they will access it. This level of security also ensures attacker should not get control on hardware and applications. This will be assured by CSPs using identity, role, key or claim based access methods. These methods will assure what type of user will see what part of the services. It reduces unintentional as well as intentional data theft and other active or passive attacks on services. [15] [16]

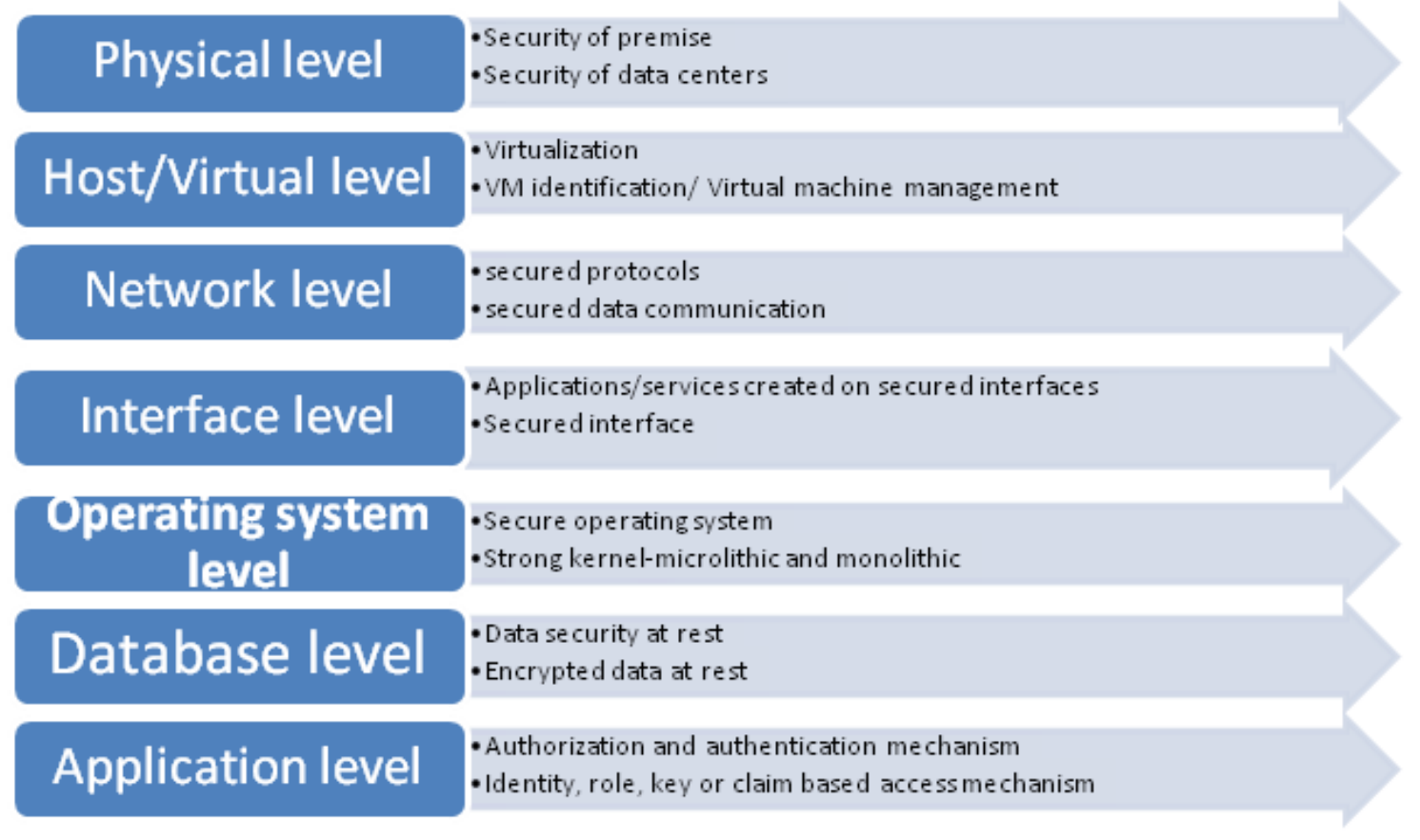

Figure 1: Security Levels in cloud computing 
Table 1: mapping of cloud service users with security levels

\begin{tabular}{|c|c|c|c|c|c|c|c|c|}
\hline \multirow[t]{2}{*}{ Users } & \multirow{2}{*}{$\begin{array}{l}\text { Type of } \\
\text { Cloud } \\
\text { Service } \\
\text { used }\end{array}$} & \multicolumn{7}{|c|}{ Security level* } \\
\hline & & $\begin{array}{l}\text { Physical } \\
\text { Level }\end{array}$ & $\begin{array}{l}\text { Host/ } \\
\text { Virtual } \\
\text { Level }\end{array}$ & $\begin{array}{l}\text { N/w } \\
\text { Level }\end{array}$ & $\begin{array}{l}\text { DB } \\
\text { level }\end{array}$ & $\begin{array}{l}\text { OS } \\
\text { Level }\end{array}$ & $\begin{array}{l}\text { Interface } \\
\text { Level }\end{array}$ & $\begin{array}{l}\text { Application } \\
\text { Level }\end{array}$ \\
\hline Naïve Users & Saas & & & & & & V & v \\
\hline $\begin{array}{l}\text { Virtualized } \\
\text { device users }\end{array}$ & SaaS & & v & & & & v & $\mathrm{v}$ \\
\hline $\begin{array}{l}\text { Application/ } \\
\text { Business } \\
\text { developers } \\
\text { or } \\
\text { researchers }\end{array}$ & \begin{tabular}{|l} 
Especially \\
PaaS
\end{tabular} & & 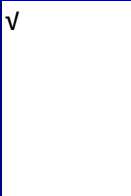 & v & v & v & & \\
\hline $\begin{array}{lr}\text { IT } & \text { System } \\
\text { Administrato } \\
\text { rs }\end{array}$ & laas & v & v & v & & & & \\
\hline
\end{tabular}

The above table shows the association between the type of users with the type of services they used and the levels of security they may need

\section{Threats and attacks in cloud computing}

National Information Assurance Glossary defines threat as any circumstance or event with the potential to adversely impact on IS or any organizational operations (including mission, functions, image, or reputation) through unauthorized access, destruction, disclosure, modification of data, and/or denial of service. Attack is a technique used by the attacker to exploit vulnerabilities and create threats to the system. Each security level shows different types of threats and vulnerable for different attacks [17].

Following are the tables, which describe attacks that can be seen under various security levels with the possible solution for each. Table 2 emphasizes physical security attacks, table 3 talks about virtual/host level security attacks; table 4 is for network level attacks, table 5 database level attacks, table 6 about operating system level attacks, table 7 demonstrates interface level attacks and finally table 8 emphasizes on application level attacks and solution. 


\subsection{Physical Security Level:}

Table 2: Physical security attacks and solution

\begin{tabular}{|c|c|c|}
\hline Attacks & Description & Solutions \\
\hline Stealing data & $\begin{array}{l}\text { Insider or outsider can steal the data from the } \\
\text { servers due to insufficient security }\end{array}$ & \multirow{6}{*}{$\begin{array}{l}\text { - Strict security } \\
\text { - } \quad \text { surveillance cameras } \\
\text { - log books which need to } \\
\text { be signed before and after } \\
\text { visiting the data centers } \\
\text { - thorough checking of } \\
\text { personnel coming and going } \\
\text { - USB slots disabling }\end{array}$} \\
\hline $\begin{array}{l}\text { Hardware } \\
\text { interruption }\end{array}$ & $\begin{array}{l}\text { System hardware is accessed by unauthorized } \\
\text { users which may denies the access to legitimate } \\
\text { users }\end{array}$ & \\
\hline $\begin{array}{l}\text { Hardware } \\
\text { theft }\end{array}$ & Due to security, hardware can be stolen & \\
\hline $\begin{array}{l}\text { Hardware } \\
\text { modification }\end{array}$ & $\begin{array}{l}\text { Unnecessary hardware modification is done by } \\
\text { unauthorized person which may deteriorate the } \\
\text { service }\end{array}$ & \\
\hline $\begin{array}{l}\text { Misuse of } \\
\text { infrastructure }\end{array}$ & $\begin{array}{l}\text { Misuse like blackmail or stealing etc can be } \\
\text { done by attacker using the existing cloud } \\
\text { infrastructure }\end{array}$ & \\
\hline $\begin{array}{l}\text { Natural } \\
\text { disasters }\end{array}$ & $\begin{array}{l}\text { Flood, Electricity failure, lightning etc. may } \\
\text { affect and fail the cloud set up }\end{array}$ & \\
\hline
\end{tabular}

\subsection{Virtual/Host Security Level:}

Table 3: Host/virtual level security threats with possible solutions

\begin{tabular}{|l|l|l|}
\hline Attacks & Description & Suggestions \\
\hline $\begin{array}{l}\text { Side channel } \\
\text { attack }\end{array}$ & $\begin{array}{l}\text { Attacker places his/her malicious VM on the } \\
\text { same physical machine and tries to extract the } \\
\text { information as a second phase of attack }\end{array}$ & $\begin{array}{l}\bullet \text { VM isolation, } \\
\text { Encrypted data at rest, } \\
\text { Stop the data leakage }\end{array}$ \\
\hline $\begin{array}{l}\text { Malware } \\
\text { injection } \\
\text { attack/Meta-d } \\
\text { ata spoofing } \\
\text { attack }\end{array}$ & $\begin{array}{l}\text { Attacker adds an extra service in the existing } \\
\text { cloud services pool and steals the data from the } \\
\text { authorized. Attacker also install any } \\
\text { mischievous software on users device }\end{array}$ & $\begin{array}{l}\text { When users log in to the } \\
\text { CSPs portal, CSP should add } \\
\text { the VM image into its image } \\
\text { storage system. This can be } \\
\text { monitored and integrity is } \\
\text { checked periodically. }\end{array}$ \\
\hline $\begin{array}{l}\text { Zombie attack } \\
\text { innocent host within the network. This may } \\
\text { lead to DOS/EDOS attack. }\end{array}$ & $\begin{array}{l}\text { Intruder adds harmful services into the list of } \\
\text { cloud provider services that may redirect valid } \\
\text { request to invalid services. }\end{array}$ & $\begin{array}{l}\bullet \\
\text { authentication system }\end{array}$ \\
\hline $\begin{array}{l}\text { Service } \\
\text { injection } \\
\text { attack }\end{array}$ & $\begin{array}{l}\text { Strong VM isolation and } \\
\text { rang is recommended }\end{array}$ \\
\hline
\end{tabular}




\begin{tabular}{|c|c|c|}
\hline VM escape & $\begin{array}{l}\text { Attacker runs a malicious script in a VM which } \\
\text { destroys the isolation layer between the VMs' } \\
\text { and can give access to other VMs as well as to } \\
\text { the host OS }\end{array}$ & \multirow{2}{*}{$\begin{array}{l}\text { - Strong Intrusion } \\
\text { Detection System and strong } \\
\text { Intrusion Prevention System } \\
\text { should be implemented. } \\
\text { - Strong VM isolation and } \\
\text { hardening needed. } \\
\text { - Also powerful firewall } \\
\text { can be implemented }\end{array}$} \\
\hline $\begin{array}{l}\text { Rootkit in } \\
\text { hypervisor }\end{array}$ & $\begin{array}{l}\text { Attacker installs a malicious hypervisor that is a } \\
\text { new Host os for other guests. This gives } \\
\text { freedom to the attacker to run any other code in } \\
\text { the environment }\end{array}$ & \\
\hline $\begin{array}{l}\text { Wrapping } \\
\text { attack }\end{array}$ & $\begin{array}{l}\text { Intruder adds malicious code in SOAP (Simple } \\
\text { Object Access Protocol) messages in Transport } \\
\text { Layer Service (TLS). This messages will then } \\
\text { saved to the server which may interrupt server } \\
\text { working }\end{array}$ & $\begin{array}{l}\text { - One extra bit-STAMP bit } \\
\text { is added in SOAP message } \\
\text { header }\end{array}$ \\
\hline VM theft & $\begin{array}{l}\text { intruder can create or shift the virtual machine } \\
\text { that gives the unauthorized control over the } \\
\text { virtual machine }\end{array}$ & \multirow{2}{*}{$\begin{array}{l}\text { - Strong Intrusion } \\
\text { Detection System and strong } \\
\text { Intrusion Prevention System } \\
\text { should be implemented } \\
\text { - Strong VM isolation and } \\
\text { hardening needed }\end{array}$} \\
\hline Hyperjacking & $\begin{array}{l}\text { Intruder can introduce a VMM(virtual machine } \\
\text { monitor) or a faulty hypervisor which may give } \\
\text { the access of all the VM available on the server }\end{array}$ & \\
\hline
\end{tabular}

\subsection{Network Security Level:}

Table 4: Network level security threats with possible solutions

\begin{tabular}{|c|c|c|}
\hline Attacks & Description & Suggestions \\
\hline Eavesdropping & $\begin{array}{l}\text { Attacker intercepts the network and listens the } \\
\text { conversation between the parties which } \\
\text { compromises the confidentiality }\end{array}$ & $\begin{array}{l}\text { - Use anti-virus softwares } \\
\text { - Implement IPSeC } \\
\text { protocol }\end{array}$ \\
\hline Replay Attack & $\begin{array}{l}\text { Intruder eavesdrop the conversation and may } \\
\text { save the data that can be used to create a new } \\
\text { connection. This time intruder gets the access of } \\
\text { the victim's account. }\end{array}$ & $\begin{array}{l}\text { - } \text { Session tokens } \\
\text { - } \text { timestamps } \\
\text { - } \quad \text { one time } \\
\text { password(OTP) } \\
\text { - Two way authentication }\end{array}$ \\
\hline In Sybil attack & $\begin{array}{l}\text { In this attack, attacker creates multiple fake } \\
\text { identities by which they contact genuine users. } \\
\text { Then it gives attacker the access to genuine } \\
\text { user's account }\end{array}$ & $\begin{array}{l}\text { - Different validation } \\
\text { techniques like identity } \\
\text { based, role based etc must be } \\
\text { implemented }\end{array}$ \\
\hline $\begin{array}{l}\text { Reused } \\
\text { address }\end{array}$ & $\begin{array}{l}\text { In cloud computing, IP of a certain service for a } \\
\text { user can be reassigned to another user. It will } \\
\text { remain in the DNS cache. It can be used by an } \\
\text { attacker to get into the system }\end{array}$ & $\begin{array}{l}\text { - ARP addresses should } \\
\text { be cleared from the cache } \\
\text { regularly }\end{array}$ \\
\hline
\end{tabular}




\begin{tabular}{|c|c|c|}
\hline DNS attack & $\begin{array}{l}\text { Attacker introduces a wrong DNS address with } \\
\text { respect to the IP address in the DNS resolver's } \\
\text { cache. This will redirect authorized users to the } \\
\text { wrong server. }\end{array}$ & $\begin{array}{l}\text { - DNSsec suite can be } \\
\text { used. } \\
\text { - Firewalls, routers having } \\
\text { ability to } \quad \text { perform } \\
\text { NAT(Network } \\
\text { Translation) should be used }\end{array}$ \\
\hline $\begin{array}{l}\text { BGP prefix } \\
\text { hijacking }\end{array}$ & $\begin{array}{l}\text { Border Gateway Protocol contains routing } \\
\text { table. Sometimes accidentally or deliberately } \\
\text { this table may get compromised and traffic may } \\
\text { get redirected to the wrong IP }\end{array}$ & $\begin{array}{l}\text { - } \quad \text { MD5/TTL } \\
\text { (Time-to-live)protection } \\
\text { - } \quad \text { Filtering options }\end{array}$ \\
\hline Sniffer attack & $\begin{array}{l}\text { If the data is not properly encrypted then } \\
\text { intruder can read the important information. }\end{array}$ & \begin{tabular}{llr} 
- & \multicolumn{2}{c}{ ARe ARP(Address } \\
resolution Protocol) \& & \&TT(Round Trip Time) & to \\
RTT & \\
detect the sniffer attack &
\end{tabular} \\
\hline Port scanning & $\begin{array}{l}\text { If any user has specified incoming packets from } \\
\text { a source to any particular port, then that port } \\
\text { becomes vulnerable to attack }\end{array}$ & $\begin{array}{l}\text { - If port scanning detected } \\
\text { then the port associated to it } \\
\text { should be stop and blocked } \\
\text { immediately }\end{array}$ \\
\hline Dos/DDos & $\begin{array}{l}\text { Attack on a particular host or a network from } \\
\text { multiple sources multiple places around the } \\
\text { world. Attack reduces availability for } \\
\text { authorized users. }\end{array}$ & $\begin{array}{l}\text { - IDS/IPS(Intrusion } \\
\text { Detection System/ Intrusion } \\
\text { Prevention System) } \\
\text { - Preventive tools like } \\
\text { switches, firewall, routers etc } \\
\text { - Strong authentication }\end{array}$ \\
\hline
\end{tabular}

\subsection{Database Security Level:}

Table 5: Database level security threats with possible solutions

\begin{tabular}{|c|c|c|}
\hline Attacks & Description & Suggestions \\
\hline $\begin{array}{l}\text { Data loss and } \\
\text { leakage }\end{array}$ & $\begin{array}{l}\text { Due to the shared nature of the cloud, this threat } \\
\text { becomes more susceptible. In this unauthorized } \\
\text { updation, deletion, removal or extraction of } \\
\text { data may happen }\end{array}$ & $\begin{array}{l}\text { - Data encryption at rest } \\
\text { - Authentication and } \\
\text { authorization } \\
\text { - backup and retention } \\
\text { policies } \\
\text { - Secure APIs and Data } \\
\text { integrity checks should be } \\
\text { implemented }\end{array}$ \\
\hline $\begin{array}{l}\text { Access data } \\
\text { and control }\end{array}$ & $\begin{array}{l}\text { Due to lack of access control mechanism, } \\
\text { confidential information can be seen or used by } \\
\text { authorized users }\end{array}$ & $\begin{array}{l}\text { - Access control } \\
\text { mechanism can be } \\
\text { implemented, } \\
\text { - Key based access, } \\
\text { various encryption techniques }\end{array}$ \\
\hline
\end{tabular}




\begin{tabular}{|c|c|c|}
\hline $\begin{array}{l}\text { Data } \\
\text { segregation }\end{array}$ & $\begin{array}{l}\text { Multi-tenant architecture helps many users to } \\
\text { have their data on the cloud simultaneously. If } \\
\text { proper separation does not implemented then } \\
\text { the data can be seen by unauthorized user. }\end{array}$ & $\begin{array}{l}\text { - techniques like data } \\
\text { validation for insecure } \\
\text { storage, } \\
\text { - SQL injection Aws etc }\end{array}$ \\
\hline Data stealing & $\begin{array}{l}\text { User's username and password is stolen and the } \\
\text { data is stolen by the attacker }\end{array}$ & $\begin{array}{l}\text { - CSPs can send an email } \\
\text { to the users for every session } \\
\text { about the time and amount for } \\
\text { the session. }\end{array}$ \\
\hline Data Location & $\begin{array}{l}\text { The location of data storage is not known to the } \\
\text { customer. The data can be kept with other } \\
\text { customers. Or the location may be not proper } \\
\text { according to the company/government policies }\end{array}$ & $\begin{array}{l}\text { - Read and understand the } \\
\text { SLA document carefully } \\
\text { before proceeding }\end{array}$ \\
\hline
\end{tabular}

\subsection{Operating System Security Level:}

Table 6: Operating system level security threats with possible solutions

\begin{tabular}{|c|c|c|}
\hline Attacks & Description & Suggestions \\
\hline $\begin{array}{l}\text { Direct access } \\
\text { attacks }\end{array}$ & $\begin{array}{l}\text { Attacker may compromise the security by } \\
\text { changing parts in OS. By doing this, attacker } \\
\text { can modify the OS also can boot another OS or } \\
\text { any other malicious application }\end{array}$ & $\begin{array}{l}\text { Trusted platform modules, } \\
\text { Disk encryption }\end{array}$ \\
\hline $\begin{array}{l}\text { Buffer } \\
\text { overflow }\end{array}$ & $\begin{array}{l}\text { Attacker control or crash the Operating system } \\
\text { by overflowing the buffer. In this data also can } \\
\text { be overwritten from the adjacent data buffer. }\end{array}$ & \multirow{2}{*}{$\begin{array}{l}\text { Patches and upgrades from a } \\
\text { valid vendors should be } \\
\text { implemented to avoid these } \\
\text { attacks }\end{array}$} \\
\hline $\begin{array}{l}\text { Unpatched } \\
\text { operating } \\
\text { systems }\end{array}$ & $\begin{array}{l}\text { Operating systems frequently have patches and } \\
\text { upgrades for existing vulnerabilities. If the host } \\
\text { operating system is not updated then the } \\
\text { attacker may exploit the OS }\end{array}$ & \\
\hline Exploit Attack & $\begin{array}{l}\text { Attacker learns from reconnaissance attack } \\
\text { about operating system running on host/guest. } \\
\text { After knowing which, attacker may exploit } \\
\text { vulnerabilities of OS }\end{array}$ & $\begin{array}{l}\text { Use of OS which uses heuristic } \\
\text { termination analysis as a part } \\
\text { of it }\end{array}$ \\
\hline
\end{tabular}




\subsection{Interface Security Level:}

Table 7: Interface level security threats with possible solutions

\begin{tabular}{|l|l|l|}
\hline Attacks & Description & Suggestions \\
\hline $\begin{array}{l}\text { Code injection } \\
\text { attack }\end{array}$ & $\begin{array}{l}\text { Malicious code is incorporated into the } \\
\text { application's interface. Which gives attacker } \\
\text { either the authentication information or } \\
\text { privileges to exploit the services more }\end{array}$ & $\begin{array}{l}\text { Use of good encryption } \\
\text { techniques }\end{array}$ \\
\hline $\begin{array}{l}\text { browser } \\
\text { hacking }\end{array}$ & $\begin{array}{l}\text { Malicious code is added into the user browsers } \\
\text { through cookies. These infected browsers can } \\
\text { help intruder to know the authentication details }\end{array}$ & $\begin{array}{l}\text { Use of antivirus applications } \\
\text { Don't save cookies }\end{array}$ \\
\hline
\end{tabular}

\subsection{Application Security Level:}

Table 8: Application level security threats with possible solutions

\begin{tabular}{|c|c|c|}
\hline Attacks & Description & Suggestion \\
\hline $\begin{array}{l}\text { SQL injection } \\
\text { attack }\end{array}$ & $\begin{array}{l}\text { Attacker inserts a malicious code into SQL } \\
\text { standard queries that gives him access to the } \\
\text { database. }\end{array}$ & $\begin{array}{l}\text { A strong user input detection and } \\
\text { sanitization systems should be } \\
\text { developed and implemented in } \\
\text { the cloud environment }\end{array}$ \\
\hline $\begin{array}{ll}\text { cross } & \text {-site } \\
\text { scripting } & \end{array}$ & $\begin{array}{l}\text { Intruder adds a code/script into the web page } \\
\text { which may be stored permanently or } \\
\text { reflected just for the time on the web page }\end{array}$ & $\begin{array}{l}\text { Various technologies like Web } \\
\text { Application Vulnerability } \\
\text { Detection Technology, Content } \\
\text { Filtering, Content Based Data } \\
\text { Leakage Prevention Technology } \\
\text { etc are available to detect and } \\
\text { mitigate the attack }\end{array}$ \\
\hline $\begin{array}{l}\text { EDos(Econom } \\
\text { ic Denial of } \\
\text { Sustainability) }\end{array}$ & $\begin{array}{l}\text { It is an attack on Pay-as-you-go model. } \\
\text { Services are used by attacker so much that it } \\
\text { obstruct economic drivers of cloud } \\
\text { computing }\end{array}$ & $\begin{array}{l}\text { Applications like EDoS-Shield } \\
\text { can help in preventing EDOS } \\
\text { attacks. It uses cloud verifier } \\
\text { node and virtual firewall which } \\
\text { filters the requests }\end{array}$ \\
\hline $\begin{array}{l}\text { Cookie } \\
\text { poisoning }\end{array}$ & Intruder can change the content of the cookie & $\begin{array}{llll}\text { Cookie } & \text { saving } & \text { should } & \text { be } \\
\text { disabled. } & \text { Cookie } & \text { cleanup } & \text { is } \\
\text { necessary } & & & \\
\end{array}$ \\
\hline $\begin{array}{l}\text { Backdoor and } \\
\text { debug options }\end{array}$ & $\begin{array}{l}\text { website debugging options if left by the } \\
\text { developer then attacker can enter into the } \\
\text { website easily and modify the content }\end{array}$ & $\begin{array}{l}\text { At the time of website } \\
\text { publishing, debug option should } \\
\text { be disabled }\end{array}$ \\
\hline $\begin{array}{l}\text { Hidden field } \\
\text { manipulation }\end{array}$ & $\begin{array}{l}\text { Hidden fields are used by the developers to } \\
\text { maintain the state. If it gets noticed then } \\
\text { attacker can use to enter in the service }\end{array}$ & $\begin{array}{l}\text { Use as less as possible of hidden } \\
\text { fields and also query strings }\end{array}$ \\
\hline
\end{tabular}




\begin{tabular}{|l|l|lr|} 
Man in the \\
middle attack & $\begin{array}{l}\text { Intruder sits in between two or more people's } \\
\text { communication. Intruder eavesdrop the } \\
\text { conversation and also can provide false } \\
\text { information to other party }\end{array}$ & $\begin{array}{l}\text { Plenty of tools like Airjack, Cain, } \\
\text { Dsniff etc can be used to prevent } \\
\text { this attack }\end{array}$ \\
\hline DOS/ DDOS & $\begin{array}{l}\text { Server becomes unavailable because of flood } \\
\text { of requests from unauthorized user/s. The } \\
\text { attackers may be placed from different parts } \\
\text { of world which contributes in DDOS attack }\end{array}$ & $\begin{array}{l}\text { IDS/IPS(Intrusion Detection } \\
\text { System),Preventive tools like } \\
\text { switches, firewall, routers etc }\end{array}$ \\
\hline
\end{tabular}

\section{Algorithm}

This paper provides an algorithm to understand what type of security measures an individual should take to have a secure cloud services experience; depending upon the type of user he/she is.

Step 1: Choose the User type from the 4 users type types mentioned earlier $U_{i}=\{1 \ldots 4\}$

Step 2: Choose the security levels needed for your user type. $\operatorname{Sec}_{i}=\{1 \ldots .7\}$

Step 3: Prioritize the levels according to your need

Step 4: Select the types of attacks according to the security levels needed. Each type of security levels has different possible attacks and their possible solutions

Step 5: Implement the security solutions from the given list or select the CSP after evaluating the effectiveness of their services on the previous solutions

The flowchart for the given algorithm can be given in figure 2 below. 


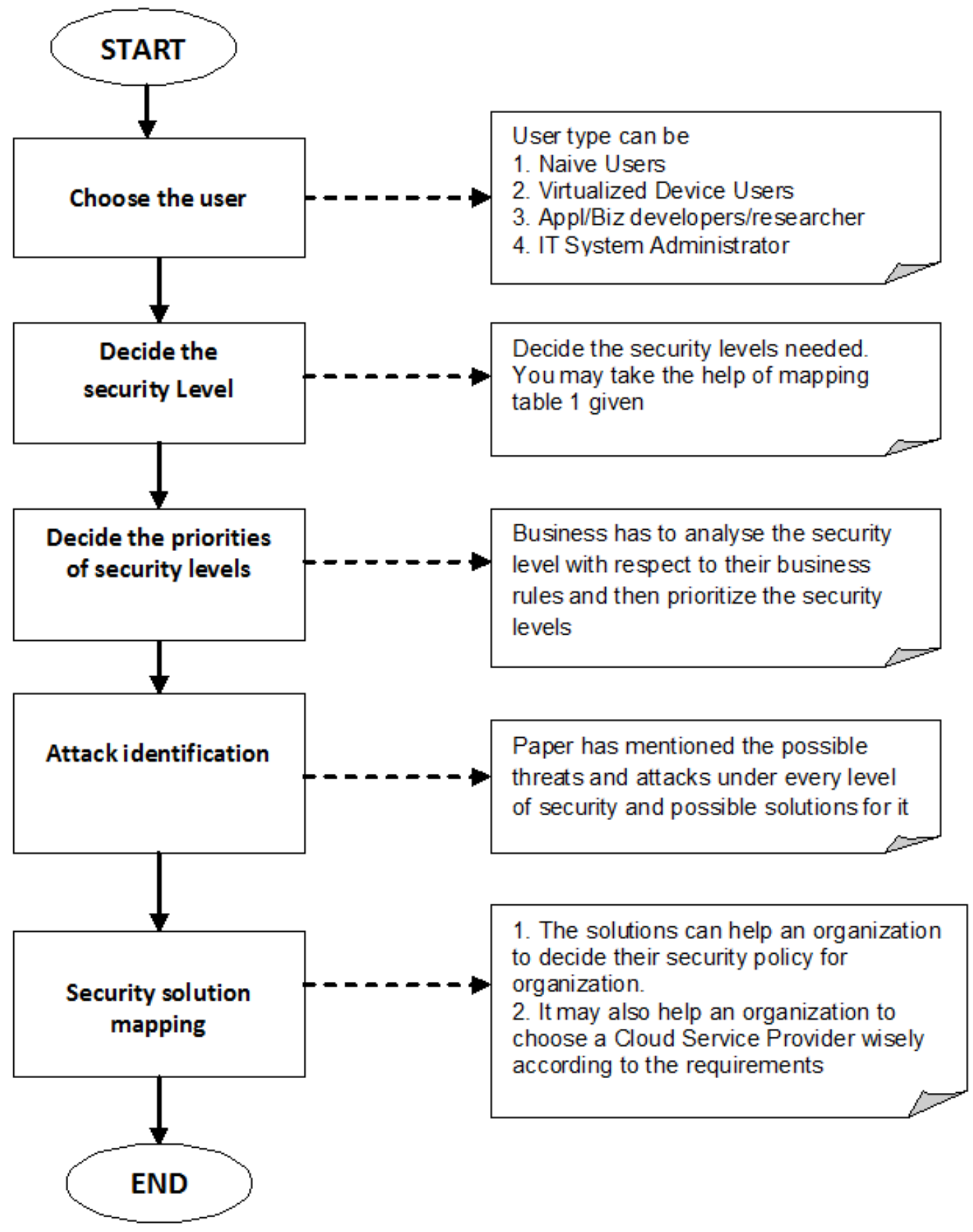

Figure 2: Detailed Flowchart for the Algorithm

\section{Explanation:}

\section{Choose the user}

The user will be selected based on the usage level. The different levels of users are defined based on their access mechanism which has to be specified as the first level of this flow

\section{Decide the security level}


With the user token, the level of security should be specified. The level of security varies with the services they want to use. These levels will show different levels of security and privacy concerns and needs.

\section{Decide the priorities of security levels}

The decision would be validated based on the business rules. This step enables the process of security levels definition more simple and realistic

\section{Attack identification}

Every security level engrossed with various possible threats and attacks. The best possible attacks are to be identified and aligned based on the priorities. The top priority attacks should be dealt with immediate effects.

\section{Security solution mapping}

As various security solutions are available in today's computer world, the solutions are to be mapped with the requirements and best possible results. The ideal solutions with multiple benefits to be identified and implemented.

\section{Case}

Mr. Kumar is a middle level manager in the sales and purchase department of garment industry, which is medium level Industry. The organization uses in-house CRM application. Now organization wants to move on cloud where they will be using CRM on cloud and employees will access it through the internet. In order to implement this, they will now have to evaluate the level of security CSPs can provide.

\section{Solution:}

S1: User level here is virtualized user (SaaS) because there will be plenty of employees from the same organization will be using the same CRM application on the cloud

S2: According to Table 1, for virtualized users (SaaS), virtual/host level, Interface level and application level security is needed.

S3: Organization may prioritize it as Application level as first, then virtual/host level and then interface level.

S4: According to the attacks and possible solutions following care should be taken by CSP and organization

- Strong VM isolation, VM hardening and appropriate IDS/IPS system should be implemented.

- Data at rest should be encrypted and data leakages should be taken care of.

- Strong authentication, input detection mechanisms should be implemented. Tools that can prevent DOS/DDOS attack can be used. Lessen the use of query strings and hidden fields. Strong content filtering should be used. 
S5: Above-mentioned measures should be checked before moving on cloud services. SLA should take care of all the above suggestions. These things should be taken into consideration when a strategic team will evaluate a CSP for adopting cloud services.

\section{Conclusion}

This study has been performed with the limited samples of four major usage categories with seven different security levels. As the cloud computing technology is cropping up rapidly, this study can be further extended by including more and more subcategories. This paper relates the different threats with the major security issues classification, which can be extended further. The effectiveness of the stated algorithm has been verified using a case analysis method. The analysis report indicates the effective functioning of the proposed algorithm. As a whole, this study provides a successful modus operandi towards a smooth ride in a cloud environment.

\section{Reference}

[1] Kimaya Ambekar, Kamatchi R., "Enhanced User Authentication Model in Cloud Computing Security”, Intelligent Systems Technologies and Applications 2016, Advances in Intelligent Systems and Computing 530, http://dx.doi.org/10.1007/978-3-319-47952-1_26, Springer International Publishing AG. 2016

[2] Bob Sutor, "Who is the user for cloud computing?", http://www.sutor.com/newsite/blog-open/?p=4548, accessed on 10/10/2016.

[3] Harpreet Saini, Amandeep Saini, "Security Mechanisms at different Levels in Cloud Infrastructure”, International Journal of Computer Applications. Volume 108 - No. 2, December 2014. http://dx.doi.org/10.5120/18880-0153

[4] Dimitrios Zissis , Dimitrios Lekkas, “Addressing cloud computing security issues”, Future Generation Computer Systems. Vol. 28, Issue 3, March 2012, Pages 583-592 http://dx.doi.org/10.1016/j.future.2010.12.006

[5] Vahid Ashktorab, Seyed Reza Taghizadeh, "Security Threats and Countermeasures in Cloud Computing”, International Journal of Application or Innovation in Engineering \& Management (IJAIEM). Volume 1, Issue 2, October 2012,

[6] R. Charanya, M.Aramudhan, K. Mohan, S. Nithya, "Levels of Security Issues in Cloud Computing”, International Journal of Engineering and Technology (IJET), Vol 5 No 2 Apr-May 2013

[7] Katerina Lourida1, Antonis Mouhtaropoulos2, Alex Vakaloudis3, “Assessing Database and Network Threats in Traditional and Cloud Computing”, International Journal of Cyber-Security and Digital Forensics (IJCSDF) 2(3): 1-17, 2013

[8] Aarti Singh, Manisha Malhotra, "Security Concerns at Various Levels of Cloud Computing Paradigm: A Review”, International Journal of Computer Networks and Applications. Vol. 2, Issue 2, March - April (2015).

[9] Computer security, https://en.wikipedia.org/wiki/Computer_security, accessed on $22 / 10 / 2016$ at $1: 50 \mathrm{pm}$

[10]

Margaret

Rouse,

"Buffer

overflow”, 


\section{Macrothink}

Network Protocols and Algorithms

ISSN 1943-3581

2016, Vol. 8, No. 4

http://searchsecurity.techtarget.com/definition/buffer-overflow, Accessed on 22/10/2016.

[11] Bogdan Popa, "Unpatched Operating Systems Could Literally Allow Hackers to Kill Patients in

Hospitals”,

http://news.softpedia.com/news/Unpatched-Operating-Systems-Could-Literally-Allow-Hacke rs-to-Kill-Patients-in-Hospitals-448595.shtml, accessed on 23/10/2016 at 5:00 pm

[12] Kashif Munir and Sellapan Palaniappan, "Security Threats/Attacks Present in Cloud Environment”, IJCSNS International Journal of Computer Science and Network Security, VOL.12 No.12, December 2012.

[13] Kashif Munir and Prof Dr. Sellapan Palaniappan, “secure cloud architecture”, Advanced Computing: An International Journal (ACIJ), Vol.4, No.1, January 2013

[14] Jaydip Sen, "Security and Privacy Issues in Cloud Computing”, Chapter 1. Architectures and Protocols for Secure Information Technology Infrastructures. IGI Global. Pp. 1-45. DOI: 10.4018/978-1-4666-4514-1.ch001

[15] Ankur Pandey,Kirtee Shevade, Roopali Soni , “Application Level Security in Cloud Computing”, (IJCSIT) International Journal of Computer Science and Information Technologies, Vol. 3 (6), 2012,5369-5373

[16] Tauseef Ahmad, Mohammad Amanul Haque, Khaled Al-Nafjan, Asrar Ahmad Ansari, "Development of Cloud Computing and Security Issues", Information and Knowledge Management. Vol.3, No.1, 2013

[17] R kamatchi, Kimaya Ambekar, "Analyzing Impacts of Cloud Computing Threats in Attack based Classification Models”, Indian Journal of Science and Technology, Vol 9(21), http://dx.doi.org/10.17485/ijst/2016/v9i21/95282, June 2016

\section{Copyright Disclaimer}

Copyright reserved by the author(s).

This article is an open-access article distributed under the terms and conditions of the Creative Commons Attribution license (http://creativecommons.org/licenses/by/3.0/). 